\title{
DOES THE FACIAL PATTERN GIVE INDIVIDUALS A PROFILE OF A CRIME SUSPECT?
}

\author{
O PADRÃO FACIAL CONFERE AOS INDIVÍDUOS O PERFIL SUSPEITO A \\ COMETER UM CRIME?
}

\section{Nathalia de Lima SANTOS ${ }^{1}$; Camila Silva de AMORIM²; Camila Barreto Rangel dos SANTOS ${ }^{1}$; Stefanni Olga Aguiar Sales LIMA ${ }^{1}$; Raildo da Silva COQUEIRO ${ }^{3}$; Luiz Renato PARANHOS ${ }^{4}$; João Pedro Pedrosa CRUZ5; Lucianne COPLE MAIA ${ }^{6}$; Matheus Melo PITHON ${ }^{7}$}

1. Student of Dentistry, Department of Healthy I, Southwest Bahia State University - UESB, Jequié, BA, Brazil; 2. Master's Degree student, Department of Pediatric Dentistry and Orthodontics, Universidade Federal do Rio de Janeiro - UFRJ, Rio de Janeiro, RJ, Brazil; 3. Professor, Department of Healthy I, Southwest Bahia State University - UESB, Jequié, BA, Brazil; 4. Professor, Department of Preventive and Social Dentistry, Federal University of Uberlândia, Uberlândia, MG, Brazil; 5. Professor Legal Medicine, Department of Healthy I - UESB, Jequié, BA, Brazil; 6. Professor, Department of Pediatric Dentistry and Orthodontics - UFRJ, Rio de Janeiro, RJ, Brazil; 7. Professor of Orthodontics, Department of Healthy I - UESB, Jequié, BA, Brazil.

\begin{abstract}
To evaluate the influence of mesofacial, brachyfacial and dolichofacial facial patterns on giving an individual the profile of a crime suspect in the eyes of public security agents. This study had a crosssectional design, conducted with public security agents of both sexes $(n=100)$, where images of facial composites (police sketches) of individuals with different facial patterns (mesofacial, brachyfacial and dolichofacial) were used. With these images in hand, a questionnaire was created, divided into three parts: the first in which all the images were presented together, allowing comparison among them; the second, in which each image was evaluated separately followed by questions and the third that consisted on a visual analog scale that presented a bar with marks going from 0 to 100, where 0 represented the untrustworthy individual, 50 the individual who could be trusted, and 100 a very trustworthy individual. When all the data had been obtained statistical analyses were performed using the Chi-square and Friedman tests. The level of significance adopted was $5 \%(\alpha=0.05)$. The dolichofacial individual was associated with security agents as the most prone to commit crimes and became more insecure and distrustful when compared to the mesofacial and brachyfacial individuals $(\mathrm{p}<0.001)$. The dolichofacial profile had a negative influence on the judgment of security agents who attributed to it, a character suspected of a crime and a low level of trustworthiness.
\end{abstract}

KEYWORDS: Face. Social perception. Judgment. Crime.

\section{INTRODUCTION}

The face is the most apparent component of the human body and consequently, the most judged, so it is not an exaggeration to say the persons are judged more by the way they appear to be than by what they really are (NAINI et al., 2008; PALOMARES et al., 2012). Although human being rapidly performs a variety of social categorizations by means of the face, understanding the exact nature of this process continues to be a challenge because the face acts as a transmitter of a multiple and complex amount of social information (JACK; SCHYNS, 2015).

The term criminality may convey the propensity to commit crimes, however, researchers also use the term to indicate the influence that the appearance of a person triggers about criminal stereotypes (LOMBROSO, 1896). Cesare Lombroso may be considered the founder of modern criminology when studying autopsies of criminals, he believed that certain physical stigmas were evident and this was proof of biological predisposition to commit crimes (CARRA; BARALE, 2004).

The Cross-Race Effect (CRE) on memory (also referred to as the Other Effect of Race or Racial Prejudice Itself) is described in the literature, and explains that human beings more favorably evaluate the facial profiles that bring characteristics similar to those of their racial group, in comparison with other groups (MALPASS; KRAVITZ, 1969). There are also evidences that there is a better memory of faces of our own age group (RHODES; ANASTASI, 2012). In spite of this theory, there is still no true consensus with respect to why this happens (HOURIHAN et al., 2013).

It is known that one of the most critical decisions that a security agent can take is to shoot or not to shoot at a criminal suspect, seeing that the 
death of an innocent person is sufficient reason for justifying the investigation into the factors that determined the decisions of this professional (MILLER et al., 2012). Although the aesthetic implications of malocclusion and facial profiles are generally considered important (SHAW et al., 1985), no research has been directed to studying the influences of these characteristics on contemporary criminology. Therefore, the aim of the present study was to evaluate whether the mesofacial, brachyfacial and dolichofacial facial patterns give individuals a suspicious profile in the eyes of public security agents, through the application of questionnaires based on the evaluation of police sketches.

\section{MATERIAL AND METHODS}

The present research was a cross-sectional study conducted with security agents of both sexes, in the city of Jequié, Bahia, Brazil who were prepared to evaluate whether the facial patterns were characteristics that made an individual suspected of having committed a crime. Security agents who had ophthalmological/visual disturbances that would hamper their evaluation of the images, and those who refused to participate in the Study, were excluded from the sample.

Initially, the sample size calculation was made by using nQuery Adviser (Version 7.0, Cork, Ireland). Based on an $(\alpha=0,05)$ the level of significance of $5 \%$, the sample size calculated was to attain the power of $80 \%$. The sample size calculation showed that the number of 100 security agent would be necessary.

Before the data collection began, the project was sent to the Research Ethics Committee, from which it received a favorable report. All the participants who answered the questionnaires signed the Free and Informed Term of Consent.

Specialists in police sketch designed for this study the same individual with three different facial patterns (mesofacial, brachyfacial and dolichofacial) (Figure 1). With these in hand, a questionnaire was created and presented in a Notebook (Toshiba, Tokyo, Japan) with a 15 inch Light Emitting Diode (LED) screen that was kept at a distance of $30 \mathrm{~cm}$ from the evaluator. Before analysis of the images, the evaluators were asked some questions with regard to sex, age, rank and time of service in the police.

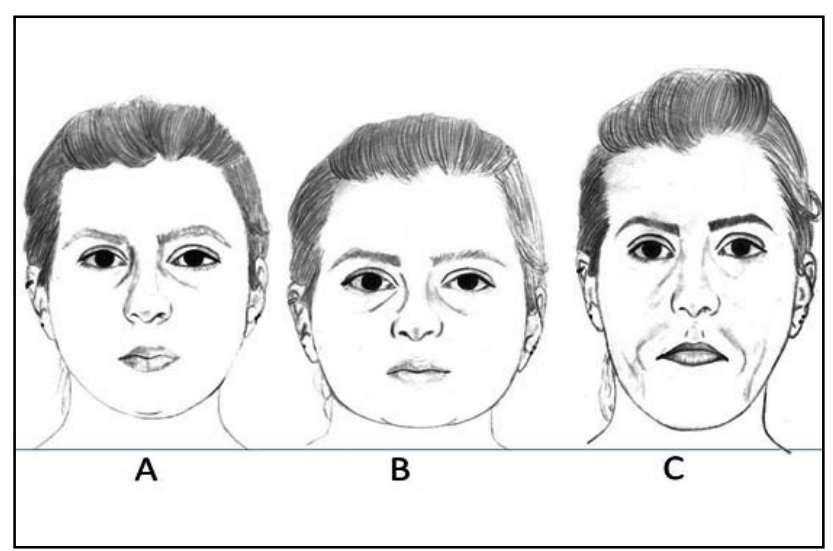

Figure 1. Police sketchs used in the present study: A - Mesofacial individual; B - Brachyfacial individual; C Dolichofacial individual.

\section{First stage of the questionnaire}

Three images were presented together, followed by the questions (1) Which of these individuals do you think maybe the author of some crime? (2) Which of these individuals gives a stronger impression of insecurity/mistrust? In the sequence of the questionnaire, the same images were presented again in changed positions, followed by the same questions. The purpose of this initial stage of the questionnaire was to evaluate the reliability of the responses given by the evaluators.

\section{Second stage of the questionnaire}

In sequence, each image was presented individually, and the following questions were asked: (1) During an approach, would you consider this individual as a suspect of committing a crime? (2) Does this individual appear to be an honest person? (3) If this individual had committed a crime, which crime or crimes would you attribute to him? (4) Do you believe that this person would react with violence when approached by the police? (5) In a situation in which you and this individual 
were unarmed, would you be reluctant to face him in a fist fight?

\section{Third stage of the questionnaire}

After answering these questions, the evaluators were invited to attribute a score related to the confidence transmitted by the image of the police sketch, using A Visual Analog Scale (VAS) $0-100 \mathrm{~mm}$ for this purpose. This scale presented a bar with marks ranging from 0-100, where 0 represented the untrustworthy, 50 trustworthy and 100 very trustworthy individual. The corresponding numerical value was noted to be tabulated and statistically evaluated. To respond to all the questions, the evaluators had the following alternatives: no, yes and I don't know. It is worth mentioning that in question 3 , which had the most common crime options, the evaluators were allowed to indicate more than one crime alternative.

\section{Statistical analysis}

The frequencies of the responses given by the evaluators were compared by means of the chisquare test. The scores of grades attributed to the image were compared by means of the Friedman test. The level of significance adopted was 5\% $(\alpha=0.05)$. The data were tabulated and analyzed in the software program IBM SPSS Statistics for Windows (SPSS Inc, v.21, Chicago, IL, USA).

\section{RESULTS}

The participants' ages ranged from 26 to 65 years with a mean of $38.2 \pm 6.2$ years. The mean time of professional service was $13,9 \pm 5,5$ years ( 3 to 30 years). In Table 1 the other characteristics of the sample are presented.

Table 1. Sociodemographic data of study participants.

\begin{tabular}{lcc}
\hline Variables & $\mathrm{n}$ & $\%$ \\
\hline Sex & & \\
Male & 80 & 80.0 \\
Female & 20 & 20.0 \\
Rank & & \\
$\quad$ Private & 72 & 72.0 \\
Sargent & 13 & 13.0 \\
Lieutenant & 9 & 9.0 \\
Captain & 6 & 6.0 \\
\hline
\end{tabular}

In Figure 2 to, the perception of the research participants is presented, with respect to the possibility of committing a crime and insecurity/mistrust corresponding to the images presented. According to the perception of the security agents interviewed, in the two images evaluated, the dolichofacial individual was associated with the greater possibility of committing a crime and transmitting more insecurity/mistrust, when compared with the mesofacial and brachyfacial individual.

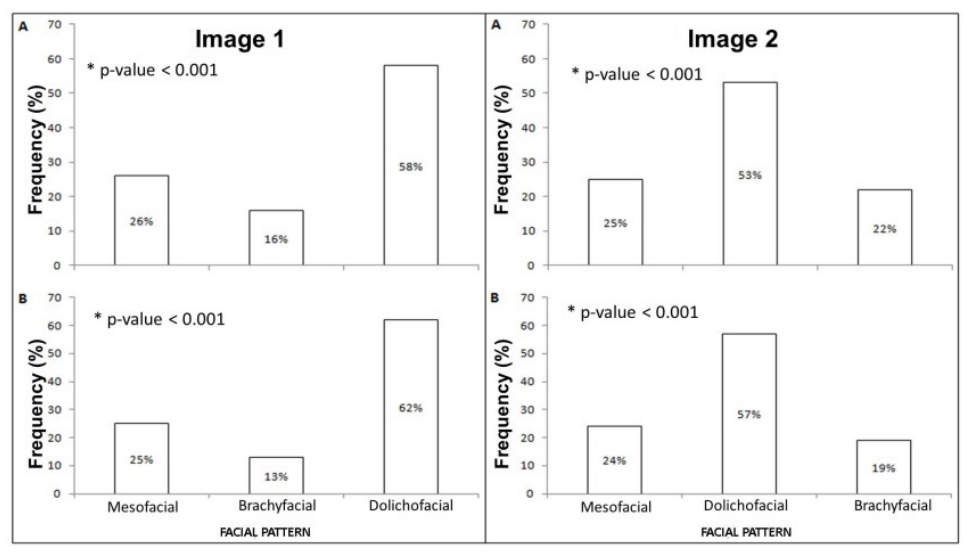

Figure 2. Responses of the study participants to the questions: (A) Which of these individuals do you think could be the author of some crime? (2) Which of these individuals transmits a stronger impression of insecurity/mistrust?

* Chi-square Test 
Table 2 presents the research participants' perception with respect to questions asked about the profiles of the individuals, according to the type of face. No significant differences were observed between any of the facial types for any of the questions asked.

Table 2. Responses of study participants, according to the survey questions on the profiles of the individuals shown in the images.

\begin{tabular}{|c|c|c|c|c|}
\hline \multirow{2}{*}{ Question } & \multicolumn{3}{|c|}{ Image } & \multirow{2}{*}{ p-value } \\
\hline & Mesofacial & Braquifacial & Dolicofacial & \\
\hline \multicolumn{5}{|c|}{ Suspected of crime } \\
\hline Yes & $40(40 \%)$ & $42(42 \%)$ & $48(48 \%)$ & \multirow{3}{*}{0,702} \\
\hline No & $22(22 \%)$ & $20(20 \%)$ & $15(15 \%)$ & \\
\hline Don't Know & $38(38 \%)$ & $38(38 \%)$ & $37(37 \%)$ & \\
\hline \multicolumn{5}{|c|}{ Appears to be honest } \\
\hline Yes & $24(24 \%)$ & $21(21 \%)$ & $15(15 \%)$ & \multirow{3}{*}{0,160} \\
\hline No & $18(18 \%)$ & $28(28 \%)$ & $32(32 \%)$ & \\
\hline Don't Know & $58(58 \%)$ & $51(51 \%)$ & $53(53 \%)$ & \\
\hline \multicolumn{5}{|c|}{ Crime assigned: simple robbery } \\
\hline Yes & $26(26 \%)$ & $23(23 \%)$ & $21(21 \%)$ & \multirow{2}{*}{0,702} \\
\hline No & $74(74 \%)$ & $77(77 \%)$ & $79(79 \%)$ & \\
\hline \multicolumn{5}{|c|}{ Crime assigned: aggravated robbery } \\
\hline Yes & $15(15 \%)$ & $17(17 \%)$ & $26(26 \%)$ & \multirow{2}{*}{0,111} \\
\hline No & $85(85 \%)$ & $83(83 \%)$ & $74(74 \%)$ & \\
\hline \multicolumn{5}{|c|}{ Crime assigned: simple filch } \\
\hline Yes & $37(37 \%)$ & $43(43 \%)$ & $27(27 \%)$ & \multirow{2}{*}{0,058} \\
\hline No & $63(63 \%)$ & $57(57 \%)$ & $73(73 \%)$ & \\
\hline \multicolumn{5}{|c|}{ Crime assigned: aggravated filch } \\
\hline Yes & $15(15 \%)$ & $17(17 \%)$ & $21(21 \%)$ & \multirow{2}{*}{0,526} \\
\hline No & $85(85 \%)$ & $83(83 \%)$ & $79(79 \%)$ & \\
\hline \multicolumn{5}{|c|}{ Crime assigned: simple homicide } \\
\hline Yes & $19(19 \%)$ & $18(18 \%)$ & $20(20 \%)$ & \multirow{2}{*}{0,937} \\
\hline No & $81(81 \%)$ & $82(82 \%)$ & $80(80 \%)$ & \\
\hline \multicolumn{5}{|c|}{ Crime assigned: aggravated homicide } \\
\hline Yes & $17(17 \%)$ & $17(17 \%)$ & $19(19 \%)$ & \multirow{2}{*}{0,912} \\
\hline No & $83(83 \%)$ & $83(83 \%)$ & $81(81 \%)$ & \\
\hline \multicolumn{5}{|c|}{ Crime assigned: gun illegal possession } \\
\hline Yes & $34(34 \%)$ & $25(25 \%)$ & $23(23 \%)$ & \multirow{2}{*}{0,178} \\
\hline No & $66(66 \%)$ & $75(75 \%)$ & $77(77 \%)$ & \\
\hline \multicolumn{5}{|c|}{ Attributable crime: drug trafficking } \\
\hline Yes & $36(36 \%)$ & $38(38 \%)$ & $48(48 \%)$ & \multirow{2}{*}{0,180} \\
\hline No & $64(64 \%)$ & $62(62 \%)$ & $52(52 \%)$ & \\
\hline \multicolumn{5}{|c|}{ Attributable crime: robbery followed by death } \\
\hline Yes & $13(13 \%)$ & $15(15 \%)$ & $19(19 \%)$ & 0403 \\
\hline No & $87(87 \%)$ & $85(85 \%)$ & $81(81 \%)$ & 0,493 \\
\hline Violent reaction & & & & \\
\hline Yes & $24(24 \%)$ & $26(26 \%)$ & $31(31 \%)$ & \\
\hline No & $27(27 \%)$ & $20(20 \%)$ & $14(14 \%)$ & 0,238 \\
\hline Don't Know & $49(49 \%)$ & $54(54 \%)$ & $55(55 \%)$ & \\
\hline I'm afraid to face & & & & \\
\hline Yes & $17(17 \%)$ & $19(19 \%)$ & $19(19 \%)$ & \\
\hline No & $57(57 \%)$ & $55(55 \%)$ & $52(52 \%)$ & 0,963 \\
\hline Don't Know & $26(26 \%)$ & $26(26 \%)$ & $29(29 \%)$ & \\
\hline
\end{tabular}

* Chi-square test. 
Comparison of the grades between the different facial types as regards the confidence transmitted is shown in Figure 3. In the perception of the policemen interviewed, the dolichofacial individual transmitted less confidence when compared with the mesofacial individual. Whereas, the score of confidence of the brachyfacial individual did not differ significantly from the scores of the mesofacial and dolichofacial individuals.

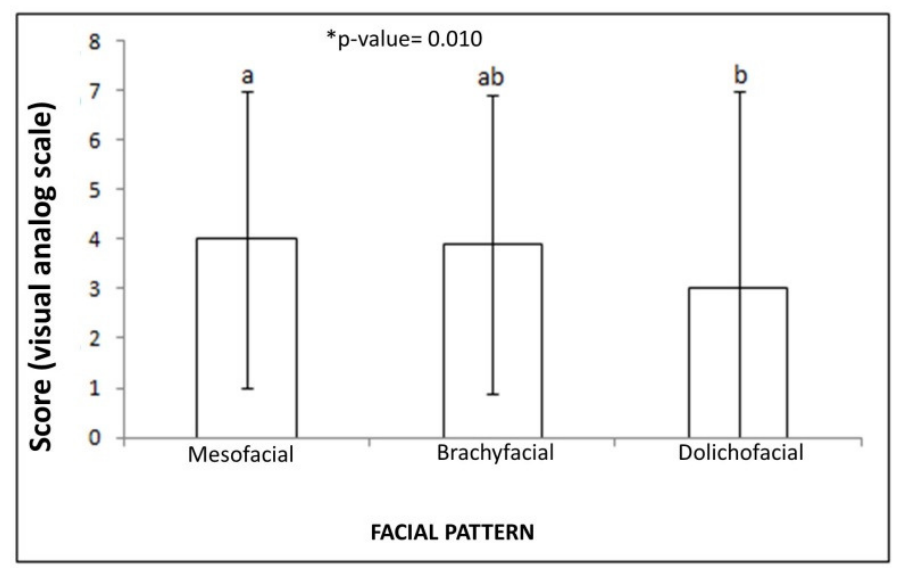

Figure 3. Grades attributed by the study participants with regard to confidence transmitted by individuals represented in the images. Columns represent means and the error bars of errors of interquartile deviations.

*Friedman Test; ${ }^{a, b}$ values with the same letter did not differ statistically between them.

\section{DISCUSSION}

Persons infer reliability from certain faces in a rapid manner and with a high level of consensus (WILLIS; TODOROV, 2006) and this is observed even when behavioral information is available (TODOROV; OLSON, 2008; RUDOY; PALLER, 2009). The faces are classified as being less trustworthy when they exhibit anger or have morphological characteristics that connotate anger, being also evaluated as having a criminal appearance. It must be taken into consideration that evaluation of facial attractiveness is subjective (PECK; PECK, 1970) and depends on multifactorial reasons, such as genetic, environmental and cultural foundations (NAINI; MOSS, 2004).

The physical characteristics of criminals are generally stereotyped, and the authors of crimes are hardly considered attractive. Criminal identification by an eye-witness must be based on memory, however, the criminal stereotypes may influence the result of identification, in which the witnesses select persons according to their personal conceptions of criminal traits (HILLS et al., 2008).

The purpose of the present study was to evaluate whether the facial patterns (mesofacial, brachyfacial and dolichofacial) give individuals the character of a crime suspect in the eyes of public security agents. The idea for the study started from the presupposition that from a social perspective, faces are important visual stimuli, and according to Frowd et al. (2014) they are the main sources of visual information about the identity, emotion, and intention of another person.

To conduct the study, images of the police sketch of one and the same individual were used with the purpose of making available to the evaluators (public security agents) the tool most commonly used by them to capture a fugitive - the police sketch. The use of the police sketch made a higher level of impartiality possible than other factors such as race, color or sex, which would interfere in the judgment of the security agents.

According to Frowd et al. (2013) it is common practice for the police to invite witnesses to help them resolve the crime, and these witnesses and victims may be a valuable resource in the initial stage of an inquiry when there is no other apparent evidence available for locating a criminal.

When evaluating the police sketches of the individual available for evaluation in the present study (mesofacial, brachyfacial and dolichofacial), the security agents associated the dolichofacial individual with being the one with most propensity to commit crimes and transmitting most insecurity and mistrust, when compared with the mesofacial and brachyfacial individuals (Fig. 2) $(\mathrm{p}<0.001)$. Other studies, such as that of Flowe et al. (2012) 
were conducted with the aim of understanding how is make judgments of criminality from facial appearance. The authors analyzed how morphologically mature traits are judged as being physically stronger, more dominant and less honest as opposed to faces that have morphologically infantile traits. These results corroborate those of the present study since the dolichofacial individuals presented stronger traits when compared with the mesofacial and brachyfacial individuals, in addition to being an elongated profile that attributed less attractiveness to it (ABU ARQOUB; ALKHATEEB, 2011).

Researches existent in this area have concentrated on situations in which the trustworthiness of the target is relevant for judicial judgment, as in the study of Wilson and Rule (2015) who used a preliminary methodology to evaluate the relationship between facial trustworthiness and real criminal sentences by means of two studies. In the first study, they were able to find that the perception of lack of trust predicted the death sentence of murderers convicted in Florida $(\mathrm{n}=742)$. Whereas, in the second study, it was verified that the link between the trustworthiness of the faces and the death sentence occurred even when the participants saw innocent persons who initially had received the death sentence, but were afterward exonerated.

The results arising from the present study are joined to those of other researches about the role of facial information in the penal sentence (BLAIR et al., 2004; EBERHARDT et al., 2006). However, never before has the facial pattern been associated with criminal characteristics. Therefore, the study adds yet another alarming datum to high impact judgments (criminal sentences), with the object of diminishing investigation biases (WILSON; RULE, 2015), and causing security agents to take political and professional decisions about the right to look carefully and attentively when judging eye-witness reports that approach persons with characteristics of the dolichofacial profile as suspects, since the results of the study could prove that this is a profile stereotyped as having more propensity to commit crime, and that transmits less trustworthiness.
Therefore, it is of the utmost importance to make these professionals aware of the facial pattern and criminal profile relationship and the potential biases that it implies, reinforcing that other evidence should be used for to convict or acquit a person accused of committing a crime, to avoid unjust condemnation.

In order to avoid that other characteristics of the people drawn in the police sketches could be a bias in the choice of the public security agents, single facial features were standardized, changing only the facial pattern among the three images. This was a methodology developed for this study, where the results are limited to the group where they were found, and caution should be taken to extrapolate to the general population. Nevertheless, further researches are necessary to determine the process by which appearance influences the criminal results and solidify the causal structure of this relationship. A parsimonious description of the factors on which criminal facial appearance are based would be of enormous theoretical and applied use, thus reducing the impact of bias of criminal faces in identifications by police sketches.

\section{CONCLUSIONS}

An individual with a dolichofacial pattern was associated with more propensity to commit crimes by the security agents;

The individual with the dolichofacial pattern transmitted more insecurity and mistrust in the public security agents when compared with mesofacial and brachyfacial individuals.

The dolichofacial profile was classified as a criminal profiler from the results of this study, however, further researches are necessary to go more deeply into the causal factor of classification of criminal profiles.

There must be an awareness of the population in general, and more specifically of the security agents, in order to reduce stereotyped judgment, thus avoiding unjust acts or convictions of innocent individuals.

RESUMO: Avaliar a influência dos padrões faciais mesofacial, braquifacial e dolicofacial em conceder um perfil de suspeito a cometer crimes aos olhos dos agentes de segurança pública. Este estudo teve delineamento transversal, realizado com agentes de segurança pública de ambos os sexos $(\mathrm{n}=100)$, onde imagens de retratos- falados de indivíduos com diferentes padrões faciais (mesofacial, braquifacial e dolicofacial) foram utilizadas. De posse dessas imagens, foi criado um questionário, dividido em três partes: a primeira em que todas as imagens foram apresentadas juntas, permitindo a comparação entre elas; a segunda, em que cada imagem foi avaliada separadamente seguida de perguntas e a terceira consistiu em uma escala analógica visual que apresentava uma barra com marcações de 0 a 100, onde 0 representava o indivíduo não 
confiável, 50 o indivíduo em quem se podia confiar, e 100 um indivíduo muito confiável. Após a obtenção dos dados, foram realizadas análises estatísticas utilizando os testes Qui-quadrado e Friedman. O nível de significância adotado foi de $5 \%(\alpha=0,05)$. O indivíduo dolicofacial foi associado pelos agentes de segurança como o mais propenso a cometer crimes e passou mais insegurança e desconfiança, quando comparado aos indivíduos mesofacial e braquifacial $(\mathrm{p}<0,001)$. O perfil dolicofacial influenciou negativamente no julgamento dos agentes de segurança que atribuíram-lhe caráter suspeito a cometer crimes e baixo grau de confiabilidade.

PALAVRAS-CHAVE: Face. Percepção social. Julgamento. Crime.

\section{REFERENCES}

ABU ARQOUB, S. H.; AL-KHATEEB, S. N. Perception of facial profile attractiveness of different anteroposterior and vertical proportions. Eur J Orthod, v. 33, n. 1, p. 103-11, Feb 2011.

https://doi.org/10.1093/ejo/cjq028

BLAIR, I. V.; JUDD, C. M.; CHAPLEAU, K. M. The influence of Afrocentric facial features in criminal sentencing. Psychol Sci, v. 15, n. 10, p. 674-9, Oct 2004. https://doi.org/10.1111/j.0956-7976.2004.00739.x

CARRA, G.; BARALE, F. Cesare Lombroso, M.D., 1835-1909. Am J Psychiatry, v. 161, n. 4, p. 624, Apr 2004. https://doi.org/10.1176/ajp.161.4.624

EBERHARDT, J. L.; DAVIES, P. G.; PURDIE-VAUGHNS, V. J.; JOHNSON, S. L. Looking deathworthy: perceived stereotypicality of Black defendants predicts capital-sentencing outcomes. Psychol Sci, v. 17, n. 5, p. 383-6, May 2006. https://doi.org/10.1111/j.1467-9280.2006.01716.x

FLOWE, H. D. Do characteristics of faces that convey trustworthiness and dominance underlie perceptions of criminality? PLoS One, v. 7, n. 6, p. e37253, 2012. https://doi.org/10.1371/journal.pone.0037253

FROWD, C. D.; JONES, S.; FODARELLA, C.; SKELTON, F.; FIELDS, S.; WILLIAMS, A.; MARSH, J. E.; THORLEY, R.; NELSON, L.; GREENWOOD, L.; DATE, L.; KEARLEY, K.; MCINTYRE, A. H.; HANCOCK, P. J. Configural and featural information in facial-composite images. Sci Justice, v. 54, n. 3, p. 215-27, May 2014. https://doi.org/10.1016/j.scijus.2013.11.001

FROWD, C. D.; SKELTON, F.; HEPTON, G.; HOLDEN, L.; MINAHIL, S.; PITCHFORD, M.; MCINTYRE, A.; BROWN, C.; HANCOCK, P. J. Whole-face procedures for recovering facial images from memory. Sci Justice, v. 53, n. 2, p. 89-97, Jun 2013. https://doi.org/10.1016/j.scijus.2012.12.004

HILLS, P. J.; LEWIS, M. B.; HONEY, R. C. Stereotype priming in face recognition: interactions between semantic and visual information in face encoding. Cognition, v. 108, n. 1, p. 185-200, Jul 2008. https://doi.org/10.1016/j.cognition.2008.03.004

HOURIHAN, K. L.; FRAUNDORF, S. H.; BENJAMIN, A. S. Same faces, different labels: generating the cross-race effect in face memory with social category information. Mem Cognit, v. 41, n. 7, p. 1021-31, Oct 2013. https://doi.org/10.3758/s13421-013-0316-7

JACK, R. E.; SCHYNS, P. G. The Human Face as a Dynamic Tool for Social Communication. Curr Biol, v. 25, n. 14, p. R621-34, Jul 20 2015. https://doi.org/10.1016/j.cub.2015.05.052

LOMBROSO, C. S. L'uomo delinquente in rapporto all'antropologia, alla giurisprudenza ed alle discipline carcerarie. 5. Torino, etc.: Fratelli Bocca, 1896.

MALPASS, R. S.; KRAVITZ, J. Recognition for faces of own and other race. J Pers Soc Psychol, v. 13, n. 4, p. 330-4, Dec 1969. https://doi.org/10.1037/h0028434 
MILLER, S. L.; ZIELASKOWSKI, K.; PLANT, E. A. The basis of shooter biases: beyond cultural stereotypes. Pers Soc Psychol Bull, v. 38, n. 10, p. 1358-66, Oct 2012. https://doi.org/10.1177/0146167212450516

NAINI, F. B.; COBOURNE, M. T.; MCDONALD, F.; DONALDSON, A. N. The influence of craniofacial to standing height proportion on perceived attractiveness. Int J Oral Maxillofac Surg, v. 37, n. 10, p. 877-85, Oct 2008. https://doi.org/10.1016/j.ijom.2008.07.022

NAINI, F. B.; MOSS, J. P. Three-dimensional assessment of the relative contribution of genetics and environment to various facial parameters with the twin method. Am J Orthod Dentofacial Orthop, v. 126, n. 6, p. 655-65, Dec 2004. https://doi.org/10.1016/j.ajodo.2003.08.034

PALOMARES, N. B.; CELESTE, R. K.; OLIVEIRA, B. H.; MIGUEL, J. A. How does orthodontic treatment affect young adults' oral health-related quality of life? Am J Orthod Dentofacial Orthop, v. 141, n. 6, p. 7518, Jun 2012. https://doi.org/10.1016/j.ajodo.2012.01.015

PECK, H.; PECK, S. A concept of facial esthetics. Angle Orthod, v. 40, n. 4, p. 284-318, Oct 1970.

RHODES, M. G.; ANASTASI, J. S. The own-age bias in face recognition: a meta-analytic and theoretical review. Psychol Bull, v. 138, n. 1, p. 146-74, Jan 2012. https://doi.org/10.1037/a0025750

RUDOY, J. D.; PALLER, K. A. Who can you trust? Behavioral and neural differences between perceptual and memory-based influences. Front Hum Neurosci, v. 3, p. 16, 2009. https://doi.org/10.3389/neuro.09.016.2009

SHAW, W. C.; REES, G.; DAWE, M.; CHARLES, C. R. The influence of dentofacial appearance on the social attractiveness of young adults. Am J Orthod, v. 87, n. 1, p. 21-6, Jan 1985. https://doi.org/10.1016/00029416(85)90170-8

TODOROV, A.; OLSON, I. R. Robust learning of affective trait associations with faces when the hippocampus is damaged, but not when the amygdala and temporal pole are damaged. Soc Cogn Affect Neurosci, v. 3, n. 3, p. 195-203, Sep 2008. https://doi.org/10.1093/scan/nsn013

WILLIS, J.; TODOROV, A. First impressions: making up your mind after a 100-ms exposure to a face. Psychol Sci, v. 17, n. 7, p. 592-8, Jul 2006. https://doi.org/10.1111/j.1467-9280.2006.01750.x

WILSON, J. P.; RULE, N. O. Facial Trustworthiness Predicts Extreme Criminal-Sentencing Outcomes. Psychol Sci, v. 26, n. 8, p. 1325-31, Aug 2015. https://doi.org/10.1177/0956797615590992 